\title{
Applying Bioassays for Investigation of Soils from Suburban Green Sites
}

\author{
Dávid Mónok ${ }^{1}$, Levente Kardos ${ }^{1}$, Sándor Attila Pabar ${ }^{1}, Z_{\text {Zsolt Kotroczó }}{ }^{1}$ \\ ${ }^{1}$ Department of Soil Science and Water Management, Faculty of Horticultural Science, Szent István University, Villányi út \\ 29-43, Budapest, Hungary \\ Monok.David@hallgato.szie.hu
}

\begin{abstract}
Urban green sites have many environmental and social benefits. As soils are key elements of these sites, investigation of their characteristics is highly recommended. In the present study, six different bioassay methods were used, together with physicochemical and chemical measurements, to investigate the soil quality in suburban green sites in Budapest, Hungary. The bioassays were carried out using test species from different taxonomic groups: Azomonas agilis and Pseudomonas fluorescens (bacteria), Sinapis alba and Lactuca sativa (plants), Folsomia candida and Eisena fetida (invertebrates) were also used. All the performed bioassays showed some extent of toxicity due to the contact with certain soil samples, however the test organisms demonstrated varying sensitivity. According to the results, dehydrogenase activity of $P$. fluorescens, germination rates of the tested plants, and reproduction of invertebrates were the most sensitive endpoints. Toxicity of soil samples could be partly explained by its $\mathrm{Cd}, \mathrm{Cr}$ and $\mathrm{Pb}$ content, since levels of these metals were far above the natural background. Our results encourage the need to investigate the soil quality in suburban green sites, as well as combining different bioassay methods during soil examinations.
\end{abstract}

Keywords: Bioassay, Urban soil, Green site, Heavy metal.

\section{Introduction}

According to numerous studies, human activities are strongly influence soil characteristics in urban areas [1-4]. Urban soils are usually having high bulk density, high $\mathrm{pH}$ and carbonate content, and often contain some pollutants, which pose potential risks to the environment [2-4]. One of the main contaminants are heavy metals, which can be accumulated at relatively high concentrations in topsoils $[2,5,6]$. Since the anthropogenic pollution of heavy metals is expected to decrease globally, urban soils can be a major source of secondary metal pollution [7].

In recent years, more and more study has been carried out to assess the soil quality in different cities. Most of them are mainly concentrated on soils influenced directly by human activities (e.g. in industrial areas, brownfields or near heavy traffic) or soils, which come easily in contact with humans (e.g. in parks or children's playgrounds) [5,8,9]. Thus we have little information about the soil characteristics of green sites in suburban areas. However, studying these soils are also an important issue, since green sites provide essential benefits to urban inhabitants (e.g air purification, water and climate regulation), and also offering habitat for terrestrial communities [10,11].

Many researchers stated that biological parameters should be taken into account during the evaluation of soil quality, besides the traditional chemical methods [12-15]. Soil bioassays are efficient methods to estimate the potential danger of different impacts on the soil [15]. Moreover, with the use of these tests, useful information can be obtained in connection with the potential environmental risks of contaminated soils [12,15]. For appropriate characterization of soils, it is recommended to use a number of taxonomically different test species, which play different roles in soil ecosystem [16,17]. Standardized methods of bacterial, plant and soil animal bioassays are also available in the literature.

The aim of the present study was to apply different bioassay methods for investigation of soils originated from various suburban green sites. Our objective was also to compare the usefulness and sensitivity of these methods. The main physicochemical and chemical parameters, including heavy metal contents of soils, were also determined. The study was conducted in Budapest city (the capital of Hungary), which has been inhabited since the ancient age, and it has a long industrial history. Since human activities had influenced soil for centuries, this city was very suitable for our research. Budapest has an area of $525 \mathrm{~km}^{2}$, but only about $16 \%$ of them is green area. Due to this low rate, it is very important to preserve these green sites in good condition, which is not possible without examining soils. 


\section{Material and methods}

The study was carried out at six green sites (covered with grass vegetation), which were located in a suburban area of Budapest (Figure 1). In each site four composite topsoil samples (containing at least 10 subsamples) were collected from the 0-20 cm soil layer. Before the examinations, soils were homogenised, air-dried and sieved (2-mm mesh). Soil texture, $\mathrm{pH}, \mathrm{CaCO}_{3}$ content, humus content, and water soluble salt content were determined according to Hungarian standard methods $[18,19]$. Trace metal $(\mathrm{Cd}, \mathrm{Co}, \mathrm{Cu}, \mathrm{Cr}, \mathrm{Ni}, \mathrm{Pb}, \mathrm{Zn})$ concentration of soil samples were measured after $\mathrm{HNO}_{3}+\mathrm{H}_{2} \mathrm{O}_{2}$ digestion by atomic absorption spectrometry.

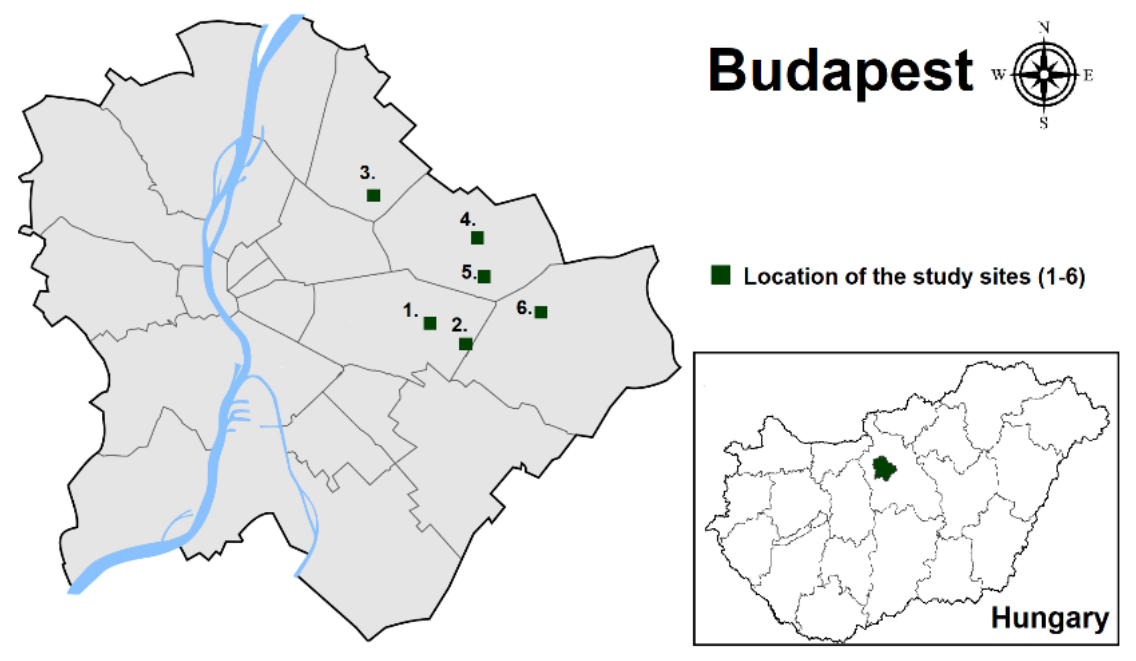

Fig. 1: Location of the study sites.

Applied bioassay methods were performed following previously published methods or OECD standards, with minor modifications (Table 1.).

Azomonas agilis bioassay: Dilution series $(1 \mathrm{~g}, 0.5 \mathrm{~g}, 0.25 \mathrm{~g}, 0.125 \mathrm{~g}, 0.0625 \mathrm{~g})$ from the soil samples were placed into test tubes and sterilized in autoclave. Then $2 \mathrm{ml}$ stock solution was added to each test tube, which contained $A$. agilis suspension in liquid Fjodorov media and TTC (2,3,5-triphenyl-tetrazolium-chloride). After that, test tubes were homogenized and incubated in the dark at $28 \pm 2{ }^{\circ} \mathrm{C}$ for 3 days. TTC is normally reducing to red-coloured triphenylformazan by microbial activity, however toxic substances in soils can inhibit this process. The inhibition was determined visually: no colour change mean $100 \%$, pink colour mean $50 \%$, while red colour mean $0 \%$ inhibition. From these results $\mathrm{IC}_{50}$ values (concentration producing $50 \%$ inhibition effect) were determined by a log-logistic dose-response model with GraphPad Prism 6 software.

Pseudomonas fluorescens bioassay: The test procedure was the same than with A. agilis. However, in this case, stock solution contained $P$. fluorescens suspension instead of $A$. agilis.

Plant bioassays: White mustard (Sinapis alba) and lettuce (Lactuca sativa) were used for plant assays. The tests were conducted by taking $30 \mathrm{~g}$ moistened soil into plastic pots (height: $40 \mathrm{~mm}$, diameter: $120 \mathrm{~mm}$ ). Then twenty-five seeds were placed into the soil surface, and the plots were incubated in the dark at $20 \pm 2{ }^{\circ} \mathrm{C}$. After 5 days germinated seeds were recorded, and the length of roots and shoots was measured with ruler.

Folsomia candida bioassay: Ten 9-12 days old juvenile springtails were transferred into the test vessels $(275 \mathrm{ml})$ containing $30 \mathrm{~g}$ moistened soil samples. Then test vessels were kept for 4 weeks at $20 \pm 2{ }^{\circ} \mathrm{C}$ temperature and $16 / 8$ light/dark cycle. During this time, springtails were fed with granulated dried baker's yeast. At the end of the test, test vessels were flooded with distilled water and the floating adult and juvenile animals were counted.

Eisena fetida bioassay: Ten adult earthworms (between 0.3 and $0.6 \mathrm{~g}$ weight) were placed into test vessels (1000 $\mathrm{ml}$ ), which contained $500 \mathrm{~g}$ moistened soil samples, and they were incubated for 4 weeks under the same condition than 
in $F$. candida test. Earthworms were fed with oatmeal during the test. After 4 weeks the living adult worms are counted and weighted. After that, these earthworms were removed from soil, which is then incubated for 4 additional weeks. At the end of the second incubation, the number of juvenile animals were also counted.

For evaluation of the measured parameters in plant test, F. candida test and E. fetida test, artificial OECD soil (70\% $\%$ quartz sand, $20 \%$ kaolinite clay and $10 \%$ sphagnum moss, $\mathrm{pH}$ 6.0 \pm 0.5 ) was used as control soil. The results were interpreted by inhibition of samples (\%) compared with the control.

Table 1: Summary of the applied bioassay methods.

\begin{tabular}{|c|c|c|c|c|}
\hline Test organisms & Endpoint of the test & Time & $\begin{array}{l}\text { Interpretation } \\
\text { of the results }\end{array}$ & Reference \\
\hline Azomonas agilis & \multirow{2}{*}{ dehydrogenase activity } & \multirow{2}{*}{3 days } & \multirow{2}{*}{$\mathrm{IC}_{50}$ value } & \multirow{2}{*}[12,14]{} \\
\hline Pseudomonas fluorescens & & & & \\
\hline Sinapis alba & \multirow{2}{*}{$\begin{array}{l}\text { germination, root and shoot } \\
\text { elongation }\end{array}$} & \multirow{2}{*}{5 days } & \multirow{4}{*}{ Inhibition (\%) } & \multirow{2}{*}[20]{} \\
\hline Lactuca sativa & & & & \\
\hline Folsomia candida & $\begin{array}{l}\text { adult's survive and } \\
\text { reproduction }\end{array}$ & 4 weeks & & {$[21]$} \\
\hline Eisena fetida & $\begin{array}{l}\text { adult's survive, adult's } \\
\text { growth and reproduction }\end{array}$ & $4+4$ weeks & & {$[22]$} \\
\hline
\end{tabular}

\section{Results}

\section{1. Physico-chemical and chemical measurements}

The physico-chemical and chemical characteristics of the tested soils are shown on Table 2. Soil texture were clay loam or sandy clay loam in all sites, except for Site 6, where it was clay. Soil pH was close to neutral in all site. In Site 1 and 5 soils were weakly calcareous, while in the other sites they were moderately calcareous. Most of the soils contain relatively high amounts of humus, only soils from Site 2 and 3 could be categorized as moderately humus-rich. Water soluble salts content were varied between $0.04 \%$ and $0.08 \%$, which values are fairly low.

Table 2: Main physico-chemical and chemical characteristics of the tested soils.

\begin{tabular}{|l|c|c|c|c|c|c|}
\hline Parameter & Site 1 & Site 2 & Site 3 & Site 4 & Site 5 & Site 6 \\
\hline Texture & $\begin{array}{c}\text { Sandy } \\
\text { clay } \\
\text { loam }\end{array}$ & $\begin{array}{c}\text { Clay } \\
\text { loam }\end{array}$ & $\begin{array}{c}\text { Clay } \\
\text { loam }\end{array}$ & $\begin{array}{c}\text { Sandy } \\
\text { clay } \\
\text { loam }\end{array}$ & $\begin{array}{c}\text { Sandy } \\
\text { clay } \\
\text { loam }\end{array}$ & Clay \\
\hline $\mathrm{pH}$ & 7.2 & 7.1 & 7.2 & 7.0 & 6.7 & 7.5 \\
\hline $\mathrm{CaCO}$ content $(\%)$ & 0.49 & 5.15 & 5.08 & 7.50 & 0.80 & 8.73 \\
\hline Humus content $(\%)$ & 3.26 & 2.44 & 2.65 & 6.02 & 4.38 & 6.38 \\
\hline Water soluble salts content $(\%)$ & 0.06 & 0.06 & 0.08 & 0.07 & 0.04 & 0.08 \\
\hline Cd content $\left(\mathrm{mg} \mathrm{kg}^{-1}\right)$ & 1.54 & 1.62 & 2.74 & 2.71 & 2.33 & 1.92 \\
\hline Co content $\left(\mathrm{mg} \mathrm{kg}^{-1}\right)$ & 7.67 & 9.20 & 14.56 & 14.1 & 14.49 & 8.68 \\
\hline $\mathrm{Cr}$ content $\left(\mathrm{mg} \mathrm{kg}^{-1}\right)$ & 93.09 & 111.87 & 220.88 & 231.15 & 248.94 & 63.73 \\
\hline Cu content $\left(\mathrm{mg} \mathrm{kg}^{-1}\right)$ & 38.63 & 28.96 & 29.77 & 31.64 & 29.94 & 37.37 \\
\hline $\mathrm{Ni}$ content $\left(\mathrm{mg} \mathrm{kg}^{-1}\right)$ & 22.91 & 20.41 & 31.28 & 37.7 & 32.20 & 37.39 \\
\hline $\mathrm{Pb}$ content $\left(\mathrm{mg} \mathrm{kg}^{-1}\right)$ & 173.00 & 198.88 & 292.80 & 209.5 & 220.69 & 209.98 \\
\hline $\mathrm{Zn}$ content $\left(\mathrm{mg} \mathrm{kg}^{-1}\right)$ & 56.07 & 39.64 & 44.78 & 45.59 & 33.03 & 48.22 \\
\hline
\end{tabular}


Trace metal contents of the tested soils were compared to the natural background values of Hungarian soils defined by [23]. Concentration of $\mathrm{Cd}, \mathrm{Cr}$ and $\mathrm{Pb}$ were much higher than background values $\left(0.5,30\right.$ and $25 \mathrm{mg} \mathrm{kg}^{-1}$ respectively) in all soil, while $\mathrm{Cu}$ and $\mathrm{Ni}$ concentration were close to these values (30 and $25 \mathrm{mg} \mathrm{kg}^{-1}$ ). In contrast, Co and $\mathrm{Zn}$ concentration of soils were below the background values (15 and $\left.100 \mathrm{mg} \mathrm{kg}^{-1}\right)$.

\section{2. Bioassay methods}

The results of the applied bioassays are summarized on Table 3. According to the results of bacterial bioassays, soil samples could be divided into 2 groups: samples from Site 1, 2 and 3 were more toxic to the dehydrogenase activity of bacterial test organisms than samples from Site 4, 5 and 6. Among the two test organisms, $P$. fluorescens was proved to be more sensitive than $A$. agilis, since $\mathrm{IC}_{50}$ values were less in its bioassay.

Results of plant bioassays showed, that soils from Site 1,2 and 3 were also highly toxic to the germination and shoot elongation of $S$. alba and L. sativa. In addition to this, soils from Site 2 and 3 were also inhibited the root elongation of plants. Soils from Site 6 were also toxic, but only to the germination rate, while samples from Site 4 and 5 were not toxic to the test plants or the degree of their toxicity was low. Between the sensitivity of the two plant bioassay, there was no clear difference.

Interestingly, results of $F$. candida and E. fetida bioassays were not in correspondence with the previous results. In $F$. candida bioassay, the number of adult animals were much less in samples from Site 3 and 4 compared with control. Soils from Site 5 and 6 only moderately decreased the number of adults, the inhibition rates were 22.7 and $14.5 \%$. Soils from Site 1 and 2 not affect this parameter. Reproduction of $F$. candida was highly inhibited (more than $50 \%$ ) by samples from Site 3, 4, 5 and 6, while samples from Site 2 moderately inhibited it with an inhibition rate of $23.7 \%$.

The tested soils were not decreased remarkably the number of E. fetida adults, however in soils from Site 3, 5 and 6 adult's growth were slightly (between 13.3 and $17.0 \%$ ) inhibited. The reproduction of E. fetida were inhibited by all the tested soil samples. The most toxic samples to this parameter were originated from Site 5, the number of juveniles were decreased on average by $71 \%$ in them compared with control.

Table 3: Effects of the tested soils on the test organisms in the applied bioassays.

\begin{tabular}{|c|c|c|c|c|c|c|c|c|}
\hline $\begin{array}{l}\text { Test } \\
\text { organisms }\end{array}$ & Endpoint of the test & $\begin{array}{c}\text { Interpretation } \\
\text { of the result }\end{array}$ & Site 1 & Site 2 & Site 3 & Site 4 & Site 5 & Site 6 \\
\hline $\begin{array}{l}\text { Azomonas } \\
\text { agilis }\end{array}$ & \multirow{2}{*}{$\begin{array}{l}\text { dehydrogenase } \\
\text { activity }\end{array}$} & \multirow{2}{*}{$\mathrm{IC}_{50}$} & 0.83 & 0.84 & 0.73 & 1.17 & 1.37 & 1.09 \\
\hline $\begin{array}{l}\text { Pseudomonas } \\
\text { fluorescens }\end{array}$ & & & 0.25 & 0.26 & 0.2 & 0.47 & 0.62 & 0.62 \\
\hline \multirow{3}{*}{ Sinapis alba } & germination rate & \multirow{11}{*}{$\begin{array}{c}\text { Inhibition } \\
(\%)\end{array}$} & 43.2 & 55.0 & 47.9 & 14.3 & 4.1 & 25.1 \\
\hline & shoot length & & 17.7 & 26.4 & 23.0 & 1.9 & 13.2 & 11.0 \\
\hline & root length & & -4.3 & 41.7 & 25.7 & -3.8 & 12.8 & -1.8 \\
\hline \multirow{3}{*}{$\begin{array}{l}\text { Lactuca } \\
\text { sativa }\end{array}$} & germination rate & & 42.2 & 57.8 & 50.6 & 17.7 & 4.8 & 37.1 \\
\hline & shoot length & & 30.4 & 47.8 & 24.1 & 13.7 & 17.5 & 6.5 \\
\hline & root length & & 8.9 & 35.4 & 22.3 & 0.2 & 11.3 & -0.9 \\
\hline \multirow{2}{*}{$\begin{array}{l}\text { Folsomia } \\
\text { candida }\end{array}$} & adult's survive & & -7.3 & 8.2 & 62.7 & 42.7 & 22.7 & 14.5 \\
\hline & reproduction & & -0.7 & 23.7 & 84.0 & 78.6 & 74.3 & 58.8 \\
\hline \multirow{3}{*}{ Eisena fetida } & adult's survive & & 0.0 & -2.6 & 7.9 & 5.3 & 5.3 & 2.6 \\
\hline & adult's growth & & 7.4 & -4.1 & 13.3 & -7.6 & 14.0 & 17.0 \\
\hline & reproduction & & 16.7 & 23.2 & 41.9 & 39.5 & 71.0 & 25.6 \\
\hline
\end{tabular}




\section{Conclusion}

According to our results, general characteristics of urban soils (e.g. high $\mathrm{pH}$, high carbonate content) were not observed observed in soil samples from suburban green sites. It was expected, since these sites had not been influenced directly by by human activities. On the contrary, trace metal concentrations of soils were far above the natural background levels in the in the case of $\mathrm{Cd}, \mathrm{Cr}$ and $\mathrm{Pb}$, which means that these metals are derived very likely from anthropogenic sources (e.g. atmospheric deposition and road traffic emissions) [5,6,24]. $\mathrm{Cr}$ is essential element for some physiological progress in low quantities, but $\mathrm{Cd}$ and $\mathrm{Pb}$ are without known biological function [6,25]. In excessive concentrations all three metal can be toxic to soil organisms [24,25].

Results of the bioassays indicated poor soil quality, since it showed that all tested soil had toxic effects on some test organisms, which could be partly explained by the high $\mathrm{Cd}, \mathrm{Cr}$ and $\mathrm{Pb}$ content of samples. However, it is important to note, that other contaminants (which were not involved in chemical analyses) may also contribute to the toxicity of these soils. The sensitivity of the test organisms and the measured endpoints varied depending on the soil. It was concluded, that soil from Site 3 were toxic according to almost all the bioassays. Samples from Site 1 and 2 were more toxic to bacteria and plants, while samples from site 4, 5 and 6 were more toxic to the invertebrates. These differences between soil samples prove the need of using different test organisms in order to assess soil quality $[12,15]$.

All in all, it was revealed, that soils from suburban green sites negatively affect various parameters of important soil organisms under laboratory conditions, which means that these soils may also harmful for terrestrial communities on sites. Therefore, in the future, much more attention should be given to the investigation of soil characteristics (especially biological parameters) in suburban green sites.

\section{Acknowledgements}

This research has been supported by the ÚNKP-19-3-I-SZIE-34. New National Excellence Program of the Ministry for Innovation and Technology, Hungary.

\section{References}

[1] S. Norra and D. Stuben, "Urban soils," Journal of Soils and Sediments, vol. 3, no. 4, pp. 230-233, 2003.

[2] M. Biasioli, R. Barberis and F. Ajmone-Marsan, "The influence of a large city on some soil properties and metals content," Science of the Total Environment, vol. 356, no. 1-3, pp. 154-164, 2006.

[3] R. V. Pouyat, I. D. Yesilonis, J. Russell-Anelli and N. K. Neerchal, "Soil chemical and physical properties that differentiate urban land-use and cover types," Soil Science Society of America Journal, vol. 71, no. 3, pp. 1010-1019, 2007.

[4] A. Lehmann and K. Stahr, "Nature and significance of anthropogenic urban soils," Journal of Soils and Sediments, vol. 7, no. 4, pp. 247-260, 2007.

[5] B. Wei and L. Yang, "A review of heavy metal contaminations in urban soils, urban road dusts and agricultural soils from China," Microchemical journal, vol. 94, no. 2, pp. 99-107, 2010.

[6] X. Liu, Q. Song, Y. Tang, W. Li, J. Xu, J. Wu and P. C. Brookes, "Human health risk assessment of heavy metals in soil-vegetable system: a multi-medium analysis," Science of the Total Environment, vol. 463, pp. 530-540, 2013.

[7] Y. N. Vodyanitskii, "Contamination of soils with heavy metals and metalloids and its ecological hazard (analytic review)," Eurasian Soil Science, vol. 46, pp. 793-801, 2013.

[8] L. Madrid, E. Díaz-Barrientos and F. Madrid, "Distribution of heavy metal contents of urban soils in parks of Seville," Chemosphere, vol. 49, no. 10, pp. 1301-1308, 2002.

[9] W. Burghardt, J. L. Morel and G. L. Zhang, "Development of the soil research about urban, industrial, traffic, mining and military areas (SUITMA)," Soil science and plant nutrition, vol. 61, no. 1, pp. 3-21, 2015.

[10] J. R. Wolch, J. Byrne and J. P. Newell, "Urban green space, public health, and environmental justice: The challenge of making cities 'just green enough'," Landscape and urban planning, vol. 125, pp. 234-244, 2014.

[11] C. Haaland and C. K. van den Bosch, "Challenges and strategies for urban green-space planning in cities undergoing densification: A review," Urban forestry \& urban greening, vol. 14, no. 1, pp. 760-771, 2015. 
[12] L. Leitgib, J. Kálmán, J. and K. Gruiz, "Comparison of bioassays by testing whole soil and their water extract from contaminated sites," Chemosphere, vol. 66, no. 3, pp. 428-434, 2007.

[13] W. Hartley, L. Uffindell, A. Plumb, H. A. Rawlinson, P. Putwain and N. M. Dickinson, "Assessing biological indicators for remediated anthropogenic urban soils," Science of the Total Environment, vol. 405, no. 1-3, pp. 359369, 2008.

[14] K. Gruiz, V. Feigl, C. Hajdu and M. Tolner, "Environmental toxicity testing of contaminated soil based on microcalorimetry," Environmental toxicology, vol. 25, no. 5, pp. 479-486, 2010.

[15] V. A. Terekhova, "Soil bioassay: problems and approaches," Eurasian Soil Science, vol. 44, no. 2, pp. 173-179, 2011.

[16] C. A. van Gestel, J. J. van der Waarde, J. G. Derksen, E. E. van der Hoek, M. F. Veul, S. Bouwens, and G. N. Stokman, "The use of acute and chronic bioassays to determine the ecological risk and bioremediation efficiency of oil-polluted soils," Environmental Toxicology and Chemistry: An International Journal, vol. 20, no. 7, pp. 1438-1449, 2001.

[17] E. J. Cardoso and P. R. L. Alves, "Soil Ecotoxicology" in Ecotoxicology, G. Begum, Ed. Rijeka: InTech Europe, 2002, pp. 27-50.

[18] MSZ-08-0206-2, “The Analyses of Chemical Soil Properties," Hungarian Standard, 1978.

[19] P. Stefanovits, Gy. Filep and Gy. Füleky, Soil Sciences. Budapest, House of Agriculture Press, 1999.

[20] OECD, “Test No. 208: Terrestrial Plant Test: Seedling Emergence and Seedling Growth Test," in: OECD Guidelines for the Testing of Chemicals, Ed. Paris: OECD Publishing, 2006.

[21] OECD, "Test No. 232: Collembolan Reproduction Test in Soil," in: OECD Guidelines for the Testing of Chemicals, Ed. Paris: OECD Publishing, 2009.

[22] OECD, "Test No. 222: Earthworm Reproduction Test (Eisenia fetida/Eisenia andrei)," in: OECD Guidelines for the Testing of Chemicals, Ed. Paris: OECD Publishing, 2016.

[23] KöM-EüM-FVM-KHVM of the Ministers of Environmental Protection, "Joint Decree No. 10/2000. Public Health, Agriculture and Regional Development, and of Traffic, Communication and Water Management on the Limit Values Necessary to Protect the Quality of Groundwater and the Geological Medium”, 2000.

[24] E. G. Pacyna, J. M. Pacyna, J. Fudala, E. Strzelecka-Jastrzab, S. Hlawiczka, D. Panasiuk and R. Friedrich, "Current and future emissions of selected heavy metals to the atmosphere from anthropogenic sources in Europe," Atmospheric Environment, vol. 41, no. 38, pp. 8557-8566, 2007.

[25] P. C. Nagajyoti, K. D. Lee and T. V. M. Sreekanth, "Heavy metals, occurrence and toxicity for plants: a review," Environmental chemistry letters, vol. 8, no. 3, pp. 199-216, 2010. 